\title{
PT2b Stage Finding
}

National Cancer Institute

\section{Source}

National Cancer Institute. pT2b Stage Finding. NCI Thesaurus. Code C48766.

A pathologic primary tumor TNM stage finding. The definition of $\mathrm{pT} 2 \mathrm{~b}$ stage finding depends on the particular type of cancer that it refers to; for example, for prostate cancer, pT 2b stage finding is defined as follows: cancer involving more than one-half of one lobe, but not both lobes of the prostate gland; for lung cancer, pT $2 \mathrm{~b}$ stage finding is defined as follows: cancer with a tumor size more than $5 \mathrm{~cm}$ but $7 \mathrm{~cm}$ or less in greatest dimension. (from AJCC 7th Ed.) 